\title{
Sources of within- and between-stand variability in specific leaf area of three ecologically distinct conifer species
}

\author{
Aaron R. WeiskitTeL ${ }^{1 *}$, Hailemariam TEMESGEN ${ }^{2}$, Duncan S. WILSON ${ }^{2}$, Douglas A. MAGUIRE \\ ${ }^{1}$ School of Forest Resources, University of Maine, Orono, ME 04469, USA \\ 2 Department of Forest Resources, Oregon State University, Corvallis, OR, 97331, USA \\ ${ }^{3}$ Department of Forest Science, Oregon State University, Corvallis, OR, 97331, USA
}

(Received 9 March 2007; accepted 16 July 2007)

\begin{abstract}
Specific leaf area (SLA) is an important ecophysiological variable, but its variability within and between stands has rarely been simultaneously examined and modeled across multiple species. Extensive datasets on SLA in coastal Douglas-fir (Pseudotsuga menziesii var. menziesii (Mirb.) Franco), hybrid spruce (Picea engelmannii Parry $\times$ Picea glauca (Moench) Voss $\times$ Picea sitchensis (Bong.) Carr.), and ponderosa pine $($ Pinus ponderosa Dougl. ex P. \& C. Laws.) were used to estimate variability of SLA within a canopy and its relationship to tree- and stand-level covariates, and to predict SLA at various locations in tree crowns. Also, in the case of hybrid spruce, variation in SLA due to different relative horizontal lengths from the bole was examined. In all species, SLA systematically increased from tree tip to crown base and decreased with foliage age class. Cardinal direction did not have a highly significant influence in either Douglas-fir or hybrid spruce, but SLA did significantly decrease from branch tip to bole in hybrid spruce. Tree- and stand-level (e.g. density, site index) factors had relatively little influence on SLA, but stand age did have a significant positive influence. For ponderosa pine, a significant relationship between canopy mean current-year SLA and carbon isotope discrimination was also found, suggesting the importance of water stress in this species. An equation was fitted to estimate SLA at various points in the canopy for each species and foliage age class using absolute height in the canopy, relative vertical height in the tree, and stand age.
\end{abstract}

specific leaf area / leaf mass area / Douglas-fir / hybrid spruce / ponderosa pine / mixed models

Résumé - Sources de variabilité intra et inter peuplements de la surface spécifique des aiguilles de trois espèce de conifère présentant des exigences écologiques contrastées. La surface spécifique des feuilles (SLA) est un paramètre écophysiologique important mais sa variabilité intra et inter-peuplements n'a jamais été examinée et modélisée sur des gammes larges d'espèces. Des jeux de données très détaillés de SLA de Douglas côtiers [Pseudotsuga menziesii var. menziesii (Mirb.) Franco], d'épicéas hybrides (Picea engelmannii Parry $\times$ Picea glauca (Moench) Voss $\times$ Picea sitchensis (Bong.) Carr), et de pins ponderosa (Pinus ponderosa Dougl. ex P. \& C. Laws.) ont été mobilisés pour évaluer la variabilité de SLA dans une canopée. Les relations entre SLA et des covariables à l'échelle de l'arbre ou du peuplement ont été précisées, un modèle prédictif de SLA à différents niveaux dans les couronnes a été construit. Dans le cas de l'épicéa, l'impact de la distance de branche entre l'aiguille et le tronc a également été testé. Dans toutes les espèces, SLA augmentait systématiquement du sommet des arbres à la base de la couronne, et diminuait avec la classe d'âge des aiguilles. La direction cardinale n'avait guère d'influence sur SLA ni dans le cas du Douglas ni dans celui de l'épicéa; mais SLA diminuait systématiquement depuis l'extrémité des branches vers le tronc. Les facteurs arbre et peuplement (comme la densité, l'indice de productivité de la station) n'avaient que peu d'impact sur SLA alors que l'âge du peuplement avait un effet significatif et positif. Pour le pin ponderosa, une relation significative a été détectée entre la valeur moyenne de SLA des aiguilles de l'année et la discrimination isotopique du carbone, ce qui suggère l'impact des contraintes hydriques pour cette espèce. Un modèle de prédiction de SLA à différentes positions dans la canopée a été ajusté sur les données de chaque espèce et classe d'âge, en se basant sur la hauteur dans la canopée, la hauteur relative dans l'arbre et l'âge du peuplement.

surface spécifique foliaire / masse surfacique des aiguilles / sapin de Douglas / épicéa hybride / pin ponderosa / modèles mixtes

\section{INTRODUCTION}

Characterizing leaf area distribution in tree crowns is important for understanding and modeling basic ecophysiological processes, developing radiation transfer models, and estimating tree growth potential. Leaf area density, however, varies widely with spatial location in the crown, among trees in a stand, and among stands over a landscape $[19,20]$. This variation is attributable in part to differences in foliage mass density, but also to differences in specific leaf area (SLA; in most species, the ratio of projected leaf area to leaf dry mass; $\mathrm{cm}^{2} \mathrm{~g}^{-1}$ ). Consequently, canopy-average SLA is an important parameter in several process-based models of forest growth

*Corresponding author: aaron@holoros.com
[30] because it or its inverse, leaf mass area (LMA; $\mathrm{g} \mathrm{cm}^{-2}$ ), implies leaf photosynthetic capacity [21] and dark respiration rate [33]. Light conditions at the time of foliage formation have generally been regarded as the primary factor influencing SLA in both hardwoods $[8,29]$ and conifers $[5,26]$. Hence, SLA within a stand generally decreases with increasing foliage age $[7,13,17]$ and with increasing height from the ground [21]. Differences in SLA from the interior to the periphery of the crown have rarely been examined; however, SLA decreased with distance from bole in both silver birch (Betula pendula Roth) [36] and old-growth Douglas-fir (Pseudotsuga menziesii var. menziesii (Mirb.) Franco) [17].

Most recent studies on SLA have generally concentrated on describing within- rather than between-stand variability 
Table I. Attributes (mean \pm standard deviation) of the Douglas-fir, hybrid spruce, and ponderosa pine datasets.

\begin{tabular}{lccc}
\hline Variable & Douglas-fir & Hybrid spruce & Ponderosa pine \\
\hline Individual branch & $N=523$ & $N=226$ & $N=338$ \\
Branch diameter (mm) & $25.59 \pm 15.42$ & $21.88 \pm 1.09$ & $31.41 \pm 12.99$ \\
Branch height above ground (m) & $22.07 \pm 8.50$ & $13.60 \pm 4.67$ & $15.43 \pm 11.21$ \\
Depth into crown (m) & $7.38 \pm 4.39$ & $5.18 \pm 3.09$ & $5.14 \pm 3.53$ \\
Relative height above crown base & $0.62 \pm 0.26$ & $0.57 \pm 0.28$ & $N=12$ \\
Individual tree & $N=64$ & $24.4 \pm 15.5$ & $N=76$ \\
Diameter at breast height (cm) & $34.9 \pm 11.7$ & $18.09 \pm 12.28$ & $30.1 \pm 7.2$ \\
Total tree height (m) & $27.39 \pm 9.03$ & $8.34 \pm 7.93$ & $19.28 \pm 4.05$ \\
Height to crown base (lowest live branch, m) & $12.32 \pm 6.53$ & $N=3$ & $8.97 \pm 3.64$ \\
Individual stand & $N=21$ & $N=12$ \\
Breast-height age (y) & $34.6 \pm 16.7$ & $66.3 \pm 50.9$ & $59.4 \pm 19.1$ \\
Leaf area index & $4.8 \pm 2.3$ & $6.1 \pm 1.1$ & $2.2 \pm 0.7$ \\
Site index (m at 50 y) & $38.6 \pm 5.5$ & $24.7 \pm 7.6$ & $31.1 \pm 3.8$ \\
\hline
\end{tabular}

$[3,16,35,36,49]$, so the generality of SLA predictive equations and their integration into process-based models remains uncertain. Across regional biomes in Oregon, the geographic distribution of mean canopy SLA was strongly correlated with leaf area index (LAI), suggesting that SLA could be accurately predicted from satellite estimates of LAI [31]. Across a variety of species, SLA has also been shown to vary inversely with leaf longevity $[14,33]$. However, Temesgen and Weiskittel [41] recently found both within- and between-stand variability of LMA to be relatively high in hybrid spruce (Picea engelmannii Parry $\times$ Picea glauca (Moench) Voss $\times$ Picea sitchensis (Bong.) Carr.). Even after accounting for foliage age class, vertical location within crown, horizontal location on branch, and stand age, the fixed effects only explained $\sim 15 \%$ of the original variation in LMA [41], suggesting that a predictive equation based on these variables would be of limited value.

Although several environmental factors influence SLA, stand-level factors such as canopy structure and silvicultural treatments are also important. In eight interior Douglas-fir (Pseudotsuga menziesii var. glauca (Beissn.) Franco) and grand fir (Abies grandis (Dougl.) Lindl.) stands, SLA was found to be sensitive to canopy position, date of sampling, and fertilization treatment, although a predictive model was not attempted [30]. Marshall and Monserud [21] concluded that only species and branch height were needed to estimate canopy SLA for process models. However, the relationship between branch height and SLA was influenced by a surrogate for light intensity or degree of shading (canopy elevational class), suggesting that stand structure had some influence on SLA [21]. In contrast, Nagel and O'Hara [25] found that SLA was not related to branch height in even-aged stands of ponderosa pine (Pinus ponderosa Dougl. ex P. \& C. Laws.), but a significant relationship did exist for multi-aged stands. Although the range in SLA for a given species is genetically controlled, incident solar radiation controls canopy average SLA and stand structure controls vertical light interception, and SLA within a given canopy [45].

The objective of this study was to assess components of variability in SLA across three ecologically-distinct conifer species, i.e., coastal Douglas-fir (Pseudotsuga menziesii var. menziesii (Mirb.) Franco), hybrid spruce, and Pacific ponderosa pine (var. ponderosa). Coastal Douglas-fir is found from the Cascade crest west to the Pacific Ocean in Oregon, Washington, and British Columbia and grows best on deep, well-aerated soils. Hybrid spruce grows from the Rocky Mountains to the Coastal Ranges in northern and central British Columbia and is tolerant of a wide variety of habitats. Pacific ponderosa pine is found east of the Cascade crest in Oregon and Washington and grows best on coarse-textured sandy soils.

A hierarchical model was developed to test the effects of specific site- and tree-level factors and to assess the general applicability of the model for estimating SLA at sites other than those sampled. One limitation of this study, however, is that there were no direct measurements of radiation or other possibly important environmental factors. Variables such as foliage age class, location in the crown, distance from the bole, and branch aspect were assumed to serve as proxies for these environmental factors.

\section{METHODS}

Three datasets were combined for the SLA analysis (Tab. I). The first was from a detailed study on Douglas-fir crown structure and the effects of Swiss needle cast (SNC; caused by Phaeocryptopus gaeumannii (T. Rohde) Petr.) [44]. The second was from intensive sampling to determine its three-dimensional distribution of leaf area within hybrid spruce crowns [40]. The final dataset was from a study that examined soil-site productivity relationships in Central Oregon ponderosa pine [46]. In the Douglas-fir and ponderosa pine datasets, projected stand leaf area index (LAI) was estimated from site-specific tree-level allometric equations, while LAI was approximated for the three hybrid spruce stands. Specific details about each dataset are described below.

\subsection{Douglas-fir}

\subsubsection{Study Area}

All plots were located in the Oregon Coast Range; within $32 \mathrm{~km}$ of the Pacific Ocean, north of Newport, Oregon (N 44 40', W $124^{\circ}$ 
$\left.4^{\prime}\right)$ and south of Astoria, Oregon ( $\left.\mathrm{N} 46^{\circ} 7^{\prime}, \mathrm{W} 123^{\circ} 45^{\prime}\right)$. The climate in this study area is humid oceanic, with a distinct dry summer and a cool, wet winter. Rainfall varies from approximately 180

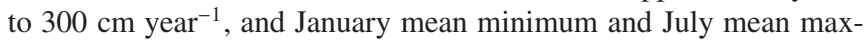
imum temperatures range from -2 to $2{ }^{\circ} \mathrm{C}$ and from 20 to $28{ }^{\circ} \mathrm{C}$, respectively [11]. Variation in precipitation and temperature for this area is strongly correlated with elevation and proximity to the coast. Elevation ranged from 45 to $550 \mathrm{~m}$ and all aspects were represented in this study.

The sampled plantations were 10- to 60-years old at breast height and contained $\geqslant 75 \%$ Douglas-fir by basal area, with varying amounts of naturally regenerated western hemlock (Tsuga heterophylla (Raf.) Sarg.) and other conifer and hardwood species. Twenty-eight stands in total were sampled for this study and were systematically chosen to represent a range of SNC severity.

\subsubsection{Data Description}

The youngest (10-30-y-old) plantations were sampled for SLA prior to budbreak in the spring of 2002, and the older (30-60-y-old) plantations were sampled in the winter of 2003-2004. In each stand, 3-5 sample trees were selected and measured for diameter at breast height (DBH), total height (HT), height to crown base (HCB), and maximum crown width $(\mathrm{CW})$. After felling the sample trees, nine to fifteen branches (2-3 whorl branches and 1-2 interwhorl branches, for a total of 3-5 per crown third) were randomly selected and transported back to the laboratory for intensive measurement. The sample branches were clipped into separate age classes, placed into smaller paper bags, and dried in an oven at a temperature of $85^{\circ} \mathrm{C}$ for three days. The needles were separated from the branch, and each component was weighed to the nearest $0.01 \mathrm{~g}$. A subsample of foliage was taken for SLA determination and nutrient analysis (Tab. II). Onesided SLA was determined on approximately 50 frozen needles with a computer image analysis system (CID Inc; Longview, WA, USA), then were dried at $80{ }^{\circ} \mathrm{C}$ for $48 \mathrm{~h}$ and weighed to the nearest $0.001 \mathrm{~g}$.

\subsection{Hybrid spruce}

\subsubsection{Study Area}

The study sites were located in the moist-cold subzone of the Interior Cedar Hemlock biogeoclimatic zone (ICHmc2), near Hazelton in northwestern British Columbia (N 55 ${ }^{\circ}$ 15', W $127^{\circ}$ 38') [6]. Sample trees were selected from three fire-origin stands with approximate ages of 20 years (S20), 60 years (S60) and 140 years (S140). The stands were chosen previously for a related study [34]. The two older stands (S60 and S140) were located within the Date Creek research area managed by the British Columbia Ministry of Forests while the youngest stand (S20) was in an adjacent wildfire known locally as the Ken Fire.

The mixed-species forests of the ICHmc2 represent a transition between true coastal and interior forests [22]. Sutton et al. [39] have shown that the spruce in this area is the hybrid Engelmann $\times$ white $\times$ Sitka spruce. Other species present in the selected stands included western hemlock, western redcedar (Thuja plicata Donn.), subalpine fir (Abies lasiocarpa (Hook.) Nutt.), lodgepole pine (Pinus contorta Dougl.) and paper birch (Betula papyrifera Marsh.).
Table II. Douglas-fir, hybrid spruce, and ponderosa pine specific leaf area data sets (mean \pm standard deviation) by foliage age class.

\begin{tabular}{lccc}
\hline Foliage age class & Douglas-fir & Hybrid spruce & Ponderosa pine \\
\hline Current & $74.62 \pm 19.07$ & $40.68 \pm 14.97$ & $30.05 \pm 3.93$ \\
& $(N=378)$ & $(N=452)$ & $(N=396)$ \\
1 & $71.09 \pm 20.47$ & $36.32 \pm 14.21$ & $24.51 \pm 2.53$ \\
& $(N=366)$ & $(N=528)$ & $(N=375)$ \\
2 & $68.56 \pm 20.18$ & $33.64 \pm 12.17$ & - \\
& $(N=316)$ & $(N=565)$ & \\
3 & $67.63 \pm 20.71$ & $32.36 \pm 11.61$ & - \\
& $(N=255)$ & $(N=561)$ & - \\
4 & $57.81 \pm 13.73$ & $32.91 \pm 12.64$ & - \\
$5+$ & $(N=102)$ & $(N=517)$ & - \\
& - & $31.67 \pm 15.21$ & - \\
\hline
\end{tabular}

\subsubsection{Data Description}

From each stand, four of the tallest hybrid spruce trees were systematically selected to have uniform crowns, straight boles, and little evidence of past crown damage. DBH was measured and the four cardinal directions were marked at breast height with different colours of paint. Each sample tree was then carefully felled and HT, HCB, and $\mathrm{CW}$ were measured. Each stem was cut at breast height, a disk was removed, and annual rings were counted (BHAGE).

On each tree, the total number of first-order branches in the quadrant facing each cardinal direction was counted. On every fourth, first-order branch in each quadrant, every fourth second-order branch (starting from the branch tip, inward) was also sampled. When a selected second-order branch had more than one third-order branch, the number of third-order branches was counted and one of them was randomly selected. The same selection procedure was used when a selected third-order branch had more than one fourth-order branch.

On each selected second-, third-, or fourth-order branch, all needles less than six years old were clipped and placed in separate paper bags by foliage age class. The needles were then removed from the twig and the one-sided leaf area (the vertical projection of needles) was measured using a leaf area meter (model CI-202, manufactured by CID Inc.). Leaf area $\left(\mathrm{cm}^{2}\right)$ and twig length $(\mathrm{cm})$ were measured on the same day as clipping occurred, to avoid measurement errors arising from leaf shrinkage. The foliage samples were then dried for $24 \mathrm{~h}$ at $80{ }^{\circ} \mathrm{C}$ and weighed to the nearest $0.01 \mathrm{~g}$ using an electronic balance. The SLA sampling scheme is described in further detail by Temesgen and Weiskittel [41].

\subsection{Ponderosa pine}

\subsubsection{Study Area}

Foliage was sampled on 11 ponderosa pine stands on the Deschutes National Forest near Bend, Oregon (N 44 6' W $121^{\circ} 18^{\prime}$ ) [46]. The region has a continental climate with long, cold winters and warm, dry summers. Precipitation falls mainly as snow during the late fall and early spring months. The elevation of the sites ranged from 1270 to $1600 \mathrm{~m}$, with average precipitation generally increasing with elevation. The sites were located in mid-rotation, pure, evenaged ponderosa pine stands. Most sites originated from natural regeneration following clearcuting, and one of the sites was a plantation. 
Sampled stands ranged in age from 25 to 95 years. Sites were chosen to span the full range of total stand foliage mass and above-ground productivity found in central Oregon. In each stand, a single 20 by $20 \mathrm{~m}$ plot was subjectively located.

\subsubsection{Data Description}

Candidate trees for destructive foliage sampling were identified outside of each plot but were selected to cover the same heights and live crown lengths as the plot trees. The 6-17 trees were randomly selected from each 4-cm diameter class of the candidate set to distribute the trees evenly across the diameter range of the plot. Sample trees were required to have good crown form and could not be adjacent to another sample tree. SLA samples were collected from a total of 76 felled trees.

Foliage sampling began in August 2000 after maximum foliage elongation and before fall foliage senescence. Each sample tree was measured for DBH and then felled into a clear area to minimize crown breakage. Each live branch was measured for basal diameter (nearest $\mathrm{mm}$ ) and for height at insertion into the bole (nearest $0.01 \mathrm{~m}$ ). Two branches were randomly selected for foliage analysis with probability proportional to $\mathrm{BD}^{2}$. Needles were sampled from the current-year and $\geqslant 1$-year foliage age classes. Samples were placed in a cooler in the field, frozen each evening, and kept frozen until area measurements. A LiCor 3100c area meter was used to determine the leaf area on a subsample of approximately $100 \mathrm{~cm}^{2}$ area. Foliage was then dried and weighed to the nearest $0.01 \mathrm{~g}$. The ${ }^{13} \mathrm{C} /{ }^{12} \mathrm{C}$ isotope ratios of current-year foliage from the upper crown third of dominant or codominant trees was expressed as $\delta^{13} \mathrm{C}$ relative to a Pee Dee belemnite standard. Foliage $\delta^{13} \mathrm{C}$ was analyzed with an isotope ratio mass spectrometer (Delta Plus, Finnigan, Bremen, Germany) at the Idaho Stable Isotopes Laboratory, University of Idaho, Moscow, Idaho, USA. Low values of $\delta^{13} \mathrm{C}$ have been shown to indicate drought stress in conifers, particularly in seasonally dry climates [43].

\subsection{Data analysis}

Multiple measurements of SLA within branches, trees, and sites imposed a hierarchical structure on the data. Error terms in the regression models were therefore not independent and not uncorrelated, so a multi-level, mixed linear model analysis was chosen. The proposed linear model was:

$$
\begin{array}{r}
\ln (\mathrm{SLA})=\mu+\mathrm{FAGE}+\mathrm{SP}+\mathrm{BD}+\mathrm{BHT}+\mathrm{Z}+\mathrm{LAI}+ \\
\text { BHAGE }+\alpha+\rho+\tau+\varepsilon
\end{array}
$$

where FAGE was foliage age class (current-year to 5-year-old), SP was species, BD was branch diameter $(\mathrm{mm})$, BHT was branch height above the ground $(\mathrm{m}), \mathrm{Z}$ was the relative branch height in the tree (BHT/tree height). Terms $\alpha, \rho$, and $\tau$ were site-, tree-, and branchlevel random effects, respectively, and $\varepsilon$ was residual error assumed to be normally distributed. FAGE was considered a categorical variable represented as a set of indicator variables, partly because the ponderosa pine dataset only distinguished between current-year and $\geqslant 1$ year foliage, unlike the other datasets. Covariates were assessed for normality using residual plots and transformed as necessary to meet the assumptions of linear regression. Significant interactions between covariates were included in the final model. Nonlinear relationships

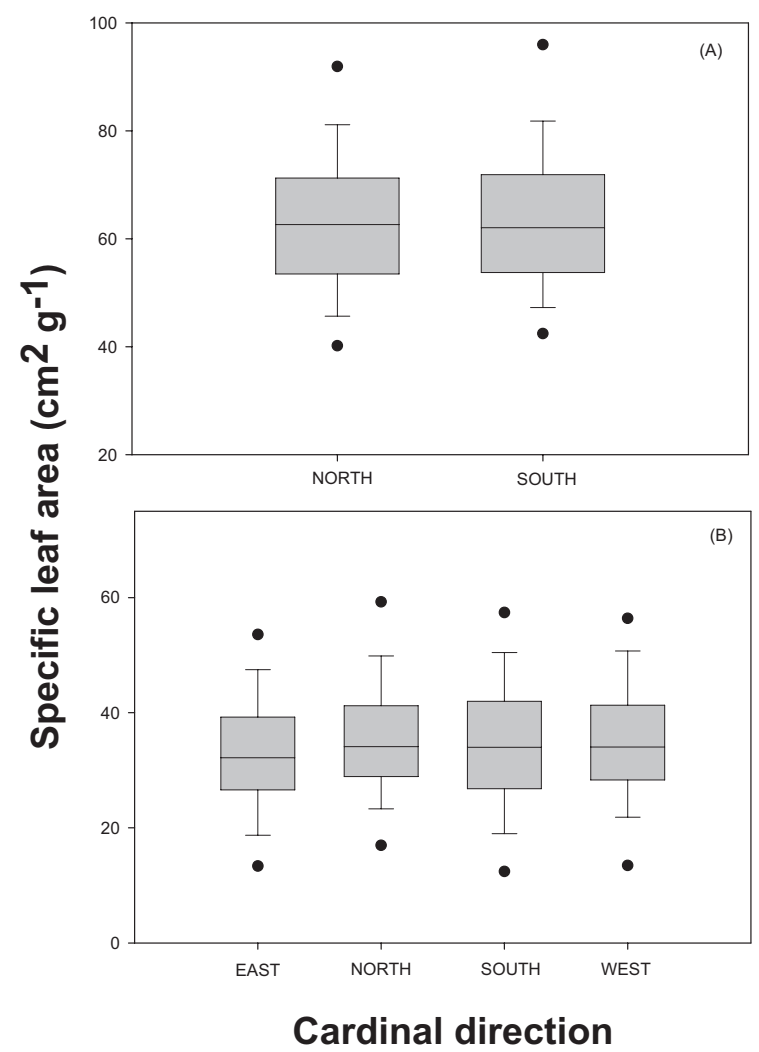

Figure 1. Box plots of specific leaf area $\left(\mathrm{cm}^{2} \mathrm{~g}^{-1}\right)$ by crown cardinal direction for Douglas-fir (graph A) and hybrid spruce (graph B).

between SLA and the independent covariates were assessed by using generalized additive mixture models (GAMM) [47]. The final model was fitted with the lme package in $R$ [32]. A power variance function of branch height and a continuous first-order autoregressive term (CAR1) as a function of distance from the tree tip were used to reduce heteroskedasticity and within-tree autocorrelation, respectively, but likelihood ratio tests indicated that only the specified CAR1 error structure significantly improved model fit.

\section{RESULTS}

In Douglas-fir, SLA of foliage from north-facing branches was not significantly different than that of south-facing branches (Fig. 1). A similar lack of difference between north and south SLA was found in hybrid spruce, but SLA tended to be significantly lower in east facing branches $(p=0.0150)$. SLA in hybrid spruce declined significantly from branch tip to bole ( $p=0.0031$ ) for a given foliage age class and fixed vertical location within the crown. In Douglas-fir and ponderosa pine, SLA declined over successively older foliage age classes (Fig. 2), but in hybrid spruce a significant decline over successively older classes was only observed for the four youngest age classes. Older stands of hybrid spruce also had a lower canopy-average SLA than younger stands $(p<0.0001)$. No significant effect of Swiss needle cast on SLA could be detected in Douglas-fir. Canopy-average SLA for current-year 


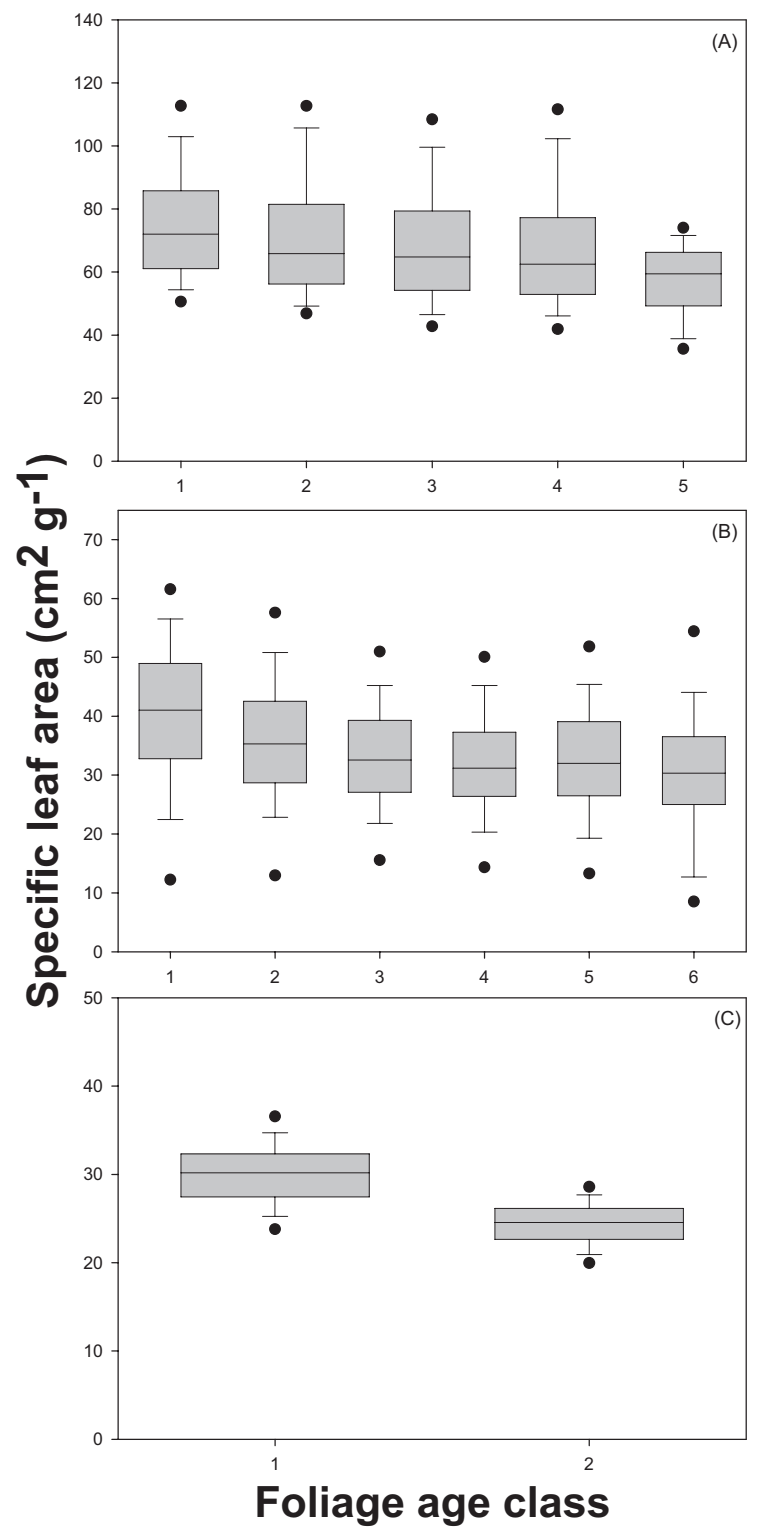

Figure 2. Box plots of specific leaf area $\left(\mathrm{cm}^{2} \mathrm{~g}^{-1}\right)$ by foliage age class for Douglas-fir (graph A), hybrid spruce (graph B), and ponderosa pine (graph C).

foliage on ponderosa pine increased as $\delta^{13} \mathrm{C}$ increased (Fig. 3), indicating greater SLA under higher site water stress.

The amount of variation attributed to each hierarchical level of sampling varied greatly by species (Tab. III). Overall, approximately $25 \%$ of the original variation in SLA was attributed to between-stand factors, while the majority of the remaining variation in the combined dataset was attributed to random tree effects (24\%) and random error (42\%).

A significant amount of autocorrelation was detected after inclusion of multi-level mixed effects, but a CAR1 error structure was effective to reduce it (Fig. 4). The percentage of variation in SLA due to within-tree factors was relatively small $(\sim 2.5 \%)$. Consequently, species significantly influenced

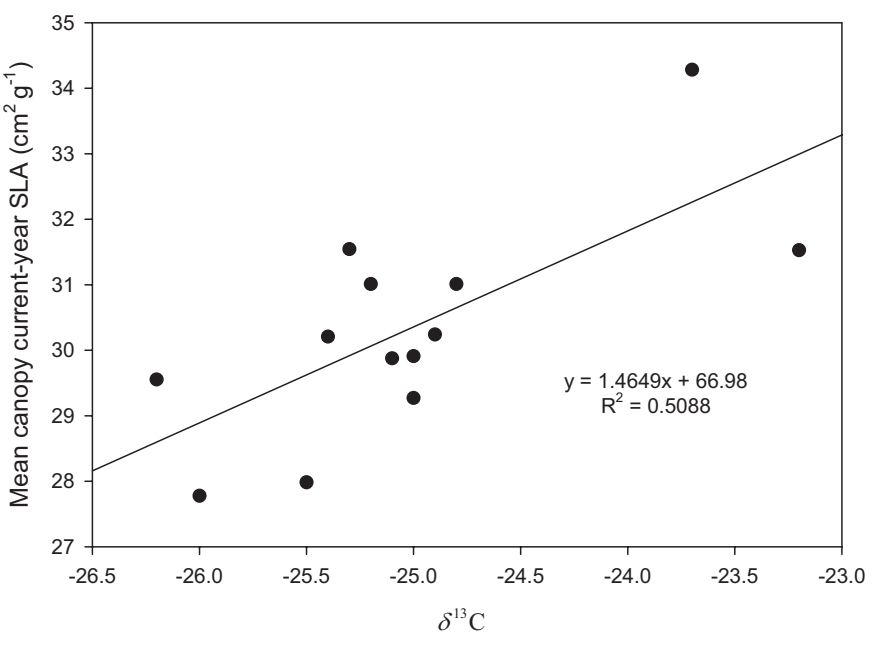

Figure 3. Relationship between canopy-average current-year specific leaf area $\left(\mathrm{cm}^{2} \mathrm{~g}^{-1}\right)$ and $\delta^{13} \mathrm{C}$ (less negative $\delta^{13} \mathrm{C}$ values indicate greater site water stress) in ponderosa pine.

Table III. Proportion of variance in specific leaf area attributed to stand, tree, and branch-level factors by species.

\begin{tabular}{lcccc}
\hline \multirow{2}{*}{ Source } & \multicolumn{3}{c}{ Species } & \multirow{2}{*}{ Overall } \\
\cline { 2 - 4 } & Douglas-fir & Hybrid spruce & Ponderosa pine & \\
\hline Stand & 0.313 & 0.008 & 0.001 & 0.266 \\
Tree & 0.064 & 0.249 & 0.051 & 0.235 \\
Branch & 0.078 & 0.059 & 0.048 & 0.079 \\
Error & 0.544 & 0.682 & 0.901 & 0.418 \\
\hline
\end{tabular}

both canopy-average SLA and the rate at which it declined in the canopy (Tab. IV). Absolute and relative height above the ground explained more of the variation in SLA than depth into the crown or canopy (Fig. 5), suggesting that location within the canopy was relatively unimportant. The rate of SLA decline with greater branch height depended on foliage age class $(p<0.0001)$, but greater foliage age was also associated with a decline in SLA. This decline in SLA over successively older foliage age classes was independent of species. After accounting for branch-level covariates, LAI had only a marginally significant influence on SLA ( $p=0.0766)$, but SLA increased significantly with stand age $(p=0.0412)$. Overall, fixed effects explained nearly $53 \%$ of the original variation in SLA. Total explained variation increased to 64,75 , and $83 \%$ when random effects at the plot-, tree-, and branch-levels were included in the model. Plot- and tree-level best linear unbiased predictors showed relatively little correlation with other covariates at either level.

In summary, canopy-average SLA was greatest for Douglas-fir and least for hybrid spruce, SLA for a given age class of foliage declined with increasing height, and SLA of older foliage at a given height was less than younger foliage at the same height (Fig. 6 and Tab. IV). 


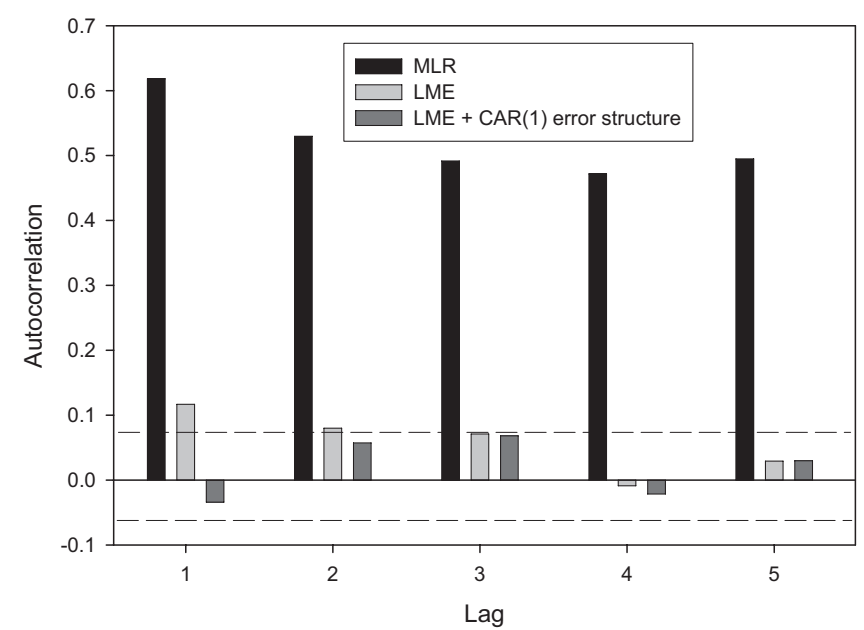

Figure 4. Autocorrelation plots for residuals from Equation (1) fitted with three different parameter estimation techniques: ordinary least square multiple linear regression (MLR), linear regression with mixed effects (LME), and mixed effects with a continuous first-order autoregressive error structure (LME + CAR(1)). Dotted lines represent $95 \%$ confidence region.

\section{DISCUSSION}

SLA is a well studied and important plant attribute, but most publications in the forestry literature have primarily examined within-stand variability for a particular species $[3,16,35,36$, 49]. Further, studies on conifer SLA have tended to focus on only a single foliage age class $[3,21,30]$. This study sought to further the understanding of SLA by combining extensive dataset in three ecologically-distinct conifer species of the $\mathrm{Pa}$ cific Northwest. Although tremendous within- and betweenstand variability in SLA was apparent for each of the three species examined, a global model that accounted for minimum SLA of each species and the effects of foliage age class, height of branch from the ground, relative height of the branch in the tree, and stand age explained a significant portion of the original variation in SLA $(\sim 55 \%)$. Other tree- and stand-level factors, including leaf area index, had little influence on SLA after accounting for these covariates. In other studies, foliage age class $[2,7,13,17]$ and branch location $[21,30]$ have consistently been key factors controlling SLA. The data collected from hybrid spruce provided a unique opportunity to test the effect of distance from bole on SLA within a branch. In this case, SLA of a given foliage age class declined with increasing distance from bole. Although we could not test this trend for Douglas-fir in our study, Ishii et al. [17] found a similar decline in SLA with increasing distance from bole in Douglas-fir old growth, particularly in the upper portion of the crown. The greater SLA of foliage close to the bole most likely is a direct result of the light environment at the time of needle development, and perhaps secondarily a response to gradients in water potential from branch base to tip.

Several alternative explanations for foliage age effects on SLA have been suggested in the past, including accumulation of nonstructural carbohydrates and other secondary substances over time [13,26], differences in growing conditions (e.g., intercepted solar radiation and annual temperature and precipitation regimes) during time of needle formation [24], and selective retention of needles with lower SLA [15]. As foliage mass is added at the top of the crown, the needles for each successive year on a given branch are formed under increasingly shaded conditions; hence, even without continued structural and biochemical development of the foliage, SLA should increase from oldest to youngest foliage at a given height. In this study, the rate at which SLA decreased with foliage age differed between species, as indicated by the significant interactions between species and branch height. Because leaf area density differs among the three species, a branch at a given relative height was expected to intercept the greatest solar radiation if it was on ponderosa pine (lowest leaf area density) and least on hybrid spruce (highest leaf area density). If true, the steepest increase in SLA with depth into crown would occur for hybrid spruce. On the contrary, Douglas-fir exhibited the most rapid increase in SLA with depth into crown. The rate of decline, however, would depend on not only the amount of leaf area accumulated per $\mathrm{m}$ depth into crown, but also on the relative shade tolerance of the species. Ishii et al. [17] found that rates of accumulation of secondary substances are greater in lower-crown branches than in upper-crown branches in mature Douglas-fir, but needles with greater SLA are also shed more rapidly. This supports the idea that rate at which SLA decreases through the canopy is dependent on foliage age class, which was found in this study.

Although light has been the most commonly cited factor influencing SLA at the branch-level [4,27], Marshall and Monserud [21] concluded that water potential was equally important because SLA was significantly related to only branch height vs. branch length or canopy elevation. Consistent with Marshall and Monserud [21] found, SLA in our study was primarily influenced by its location in the tree and canopy, and was not significantly related to either individual branch diameter or length. Unfortunately, radiation measurements were not available in any of the datasets examined in this study, so the relative control exerted by solar radiation compared to water potential is impossible to assess in our study.

At the tree-level, SLA can be influenced by tree size. In Norway spruce (Picea abies (L.) Karst.), SLA was correlated with tree height [28] and diameter [15]. St. Clair [38] indicated that tree size was negatively correlated with SLA in Douglasfir, as larger trees tended to have heavier, thicker needles. He also found little genetic variation in SLA across several coastal Douglas-fir families. In our study of three different conifers including coastal Douglas-fir, tree size had very little influence on SLA despite the wide range in diameter, height, and crown length that was represented. The combination of absolute height above ground and relative position in tree may have indirectly accounted for effects of tree social position and negated the marginal influence of other tree-level covariates.

Between-stand variability in SLA was large, but after accounting for species and several branch-level factors, only stand age was significantly related to SLA. Increasing stand age was associated with greater SLA, perhaps due to the effects of lower water potentials and greater water stress on the 

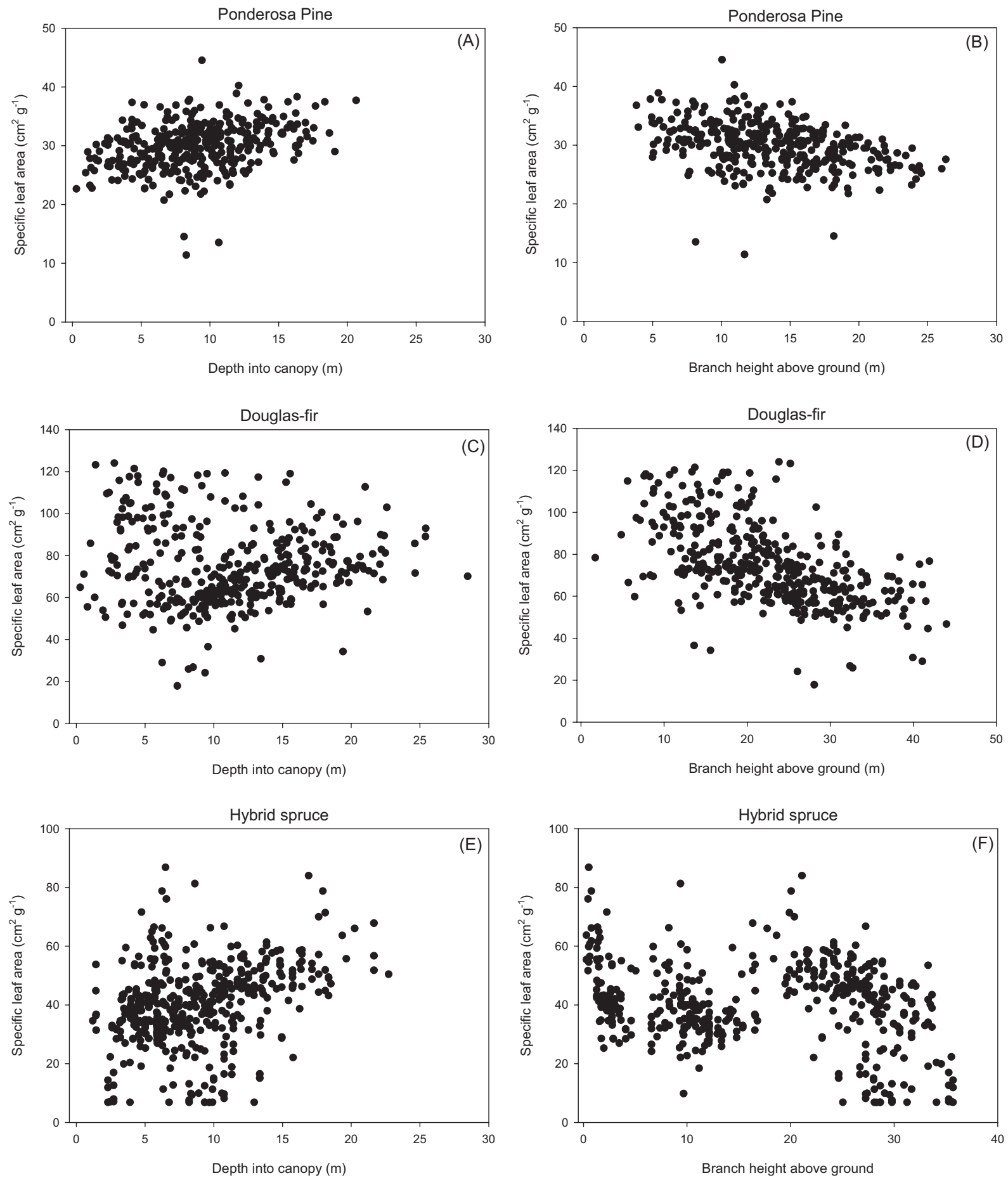

Figure 5. Relationship between specific leaf area $\left(\mathrm{cm}^{2} \mathrm{~g}^{-1}\right)$ of current-year foliage and depth into canopy (m; graphs A, C, and E) or branch height above ground ( $\mathrm{m}$; graphs B, D, and F), for ponderosa pine, Douglas-fir and hybrid spruce. 
Table IV. Parameter estimates and standard errors for linear regression model (equation [1]) for predicting the natural log of specific leaf area $\left(\mathrm{cm}^{2} \mathrm{~g}^{-1}\right)$. Base model represents current-year foliage of Douglas-fir, BHT is branch height above ground $(\mathrm{m}), \mathrm{Z}$ is the relative branch height in the tree, BHAGE is mean stand breast-height age (years), and $\mathrm{FAGE}_{k}$ is an indicator variable for foliage $\mathrm{k}$ years older than current foliage.

\begin{tabular}{|c|c|c|}
\hline Parameter & Estimate & Standard error \\
\hline Intercept & 4.9487 & 0.0709 \\
\hline $\mathrm{FAGE}_{1}$ & -0.2122 & 0.0180 \\
\hline $\mathrm{FAGE}_{2}$ & -0.2781 & 0.0219 \\
\hline $\mathrm{FAGE}_{3}$ & -0.3135 & 0.0229 \\
\hline $\mathrm{FAGE}_{4}$ & -0.3467 & 0.0242 \\
\hline $\mathrm{FAGE}_{5}$ & -0.3778 & 0.0404 \\
\hline Ponderosa pine & -1.4609 & 0.0969 \\
\hline Hybrid spruce & -0.8669 & 0.1181 \\
\hline BHT & -0.0239 & 0.0031 \\
\hline Z & -0.2539 & 0.0784 \\
\hline BHAGE & 0.0032 & 0.0015 \\
\hline $\mathrm{FAGE}_{1} \times \mathrm{BHT}$ & 0.0046 & 0.0009 \\
\hline $\mathrm{FAGE}_{2} \times \mathrm{BHT}$ & 0.0055 & 0.0011 \\
\hline $\mathrm{FAGE}_{3} \times \mathrm{BHT}$ & 0.0056 & 0.0010 \\
\hline $\mathrm{FAGE}_{4} \times \mathrm{BHT}$ & 0.0063 & 0.0011 \\
\hline Ponderosa pine $\times \mathrm{BHT}$ & 0.0135 & 0.0041 \\
\hline Hybrid spruce $\times \mathrm{BHT}$ & -0.0122 & 0.0035 \\
\hline Plot random effect & - & 0.1264 \\
\hline Tree random effect & - & 0.0979 \\
\hline Branch random effect & - & 0.1148 \\
\hline Residual & - & 0.2227 \\
\hline CAR1 & 0.2211 & - \\
\hline
\end{tabular}

structural and biochemical development of foliage on older and taller trees. Apple et al. [1] found that needles in young saplings ( $\sim 10$ years-old) were longer and had proportionately smaller vascular cylinders, larger resin canals and few hypodermal cells when compared to needles on mature trees ( $\sim 450$ years-old). In addition, mean needle thickness was $\sim 9 \%$ lower when needles from 20 to 40 years-old trees were compared to mature trees [1]. Kennedy [18] found that specific leaf weight (1/SLA) in the upper canopy of Douglas-fir and lodgepole pine (Pinus contorta var. latifolia Dougl.) was correlated with precipitation, but more strongly correlated with canopy light environment. Pierce et al. [31] concluded that canopyaverage SLA was determined primarily by environmental conditions rather than species-specific characteristics when examining vegetation over a gradient of biomes. Leaf area index was particularly effective for predicting canopy-average SLA in their study, accounting for nearly $82 \%$ of the original variation [31]. In our study of trends within a species, environmental factors such as precipitation and stand structural attributes such as leaf area index and leaf area density failed to significantly influence SLA. However, the lack of significant stand-level covariates may reflect the lack of detailed environmental measurements at each stand. Stands in geographic locations characterized by mostly direct beam radiation have been shown to have lower SLA than stands in locations with relatively low direct beam radiation but higher diffuse radiation (e.g. [37]). White and Scott [45] recently found that rel-
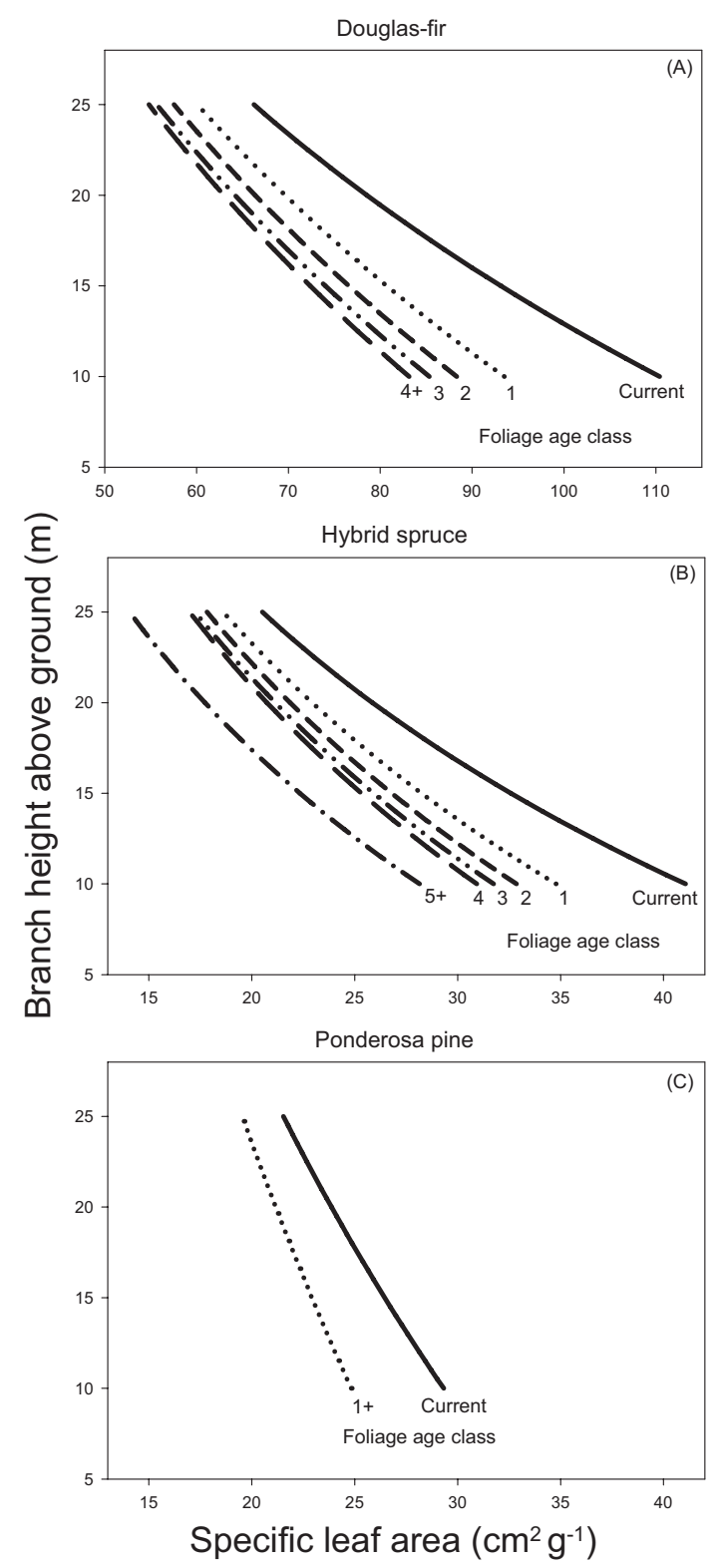

Figure 6. Predicted trend in specific leaf area $\left(\mathrm{cm}^{2} \mathrm{~g}^{-1}\right)$ for Douglasfir (A), hybrid spruce (B), and ponderosa pine $(\mathrm{C})$ by height above ground $(\mathrm{m})$ and foliage age class.

ative light interception explained over $50 \%$ of the variation in SLA within several mixed and single species stands in New Zealand.

In our analysis, canopy-average SLA for ponderosa pine current-year foliage increased with greater site water stress, indicating that other environmental factors besides radiation can have a significant influence on SLA. $\delta^{13} \mathrm{C}$, the index of water stress in our study, is physiologically related to a ratio of the photosynthetic rate $\left(A_{\mathrm{n}}\right)$ to stomatal conductance $\left(g_{\mathrm{s}}\right)$ $[10,42]$. As $A_{\mathrm{n}}$ increases for a given $g_{\mathrm{s}}$, discrimination of the heavier carbon isotope ${ }^{13} \mathrm{C}$ will decrease due to substrate limitations at the site of carboxylation [10]. Photosynthetic rate 
(for a given $g_{\mathrm{s}}$ and light intensity) is expected to be linearly related to leaf nitrogen concentration ([N]) for the low values of $[\mathrm{N}]$ 's found at the ponderosa pine sites [3,9]. The relationship between $A_{\mathrm{n}}$ and $g_{\mathrm{s}}$ is not linear because $g_{\mathrm{s}}$ increases faster than $A_{\mathrm{n}}$ in response to increasing water availability [23]. Currentyear foliage was sampled near the top of the canopy for $[\mathrm{N}]$ and $\delta^{13} \mathrm{C}$, so light stress was unlikely. Only a weak correlation was found between $\delta^{13} \mathrm{C}$ and $[\mathrm{N}],(r=-0.33, p=0.24)$ [46], which suggested that not all the variation in the $\delta^{13} \mathrm{C}$ values were due to $[\mathrm{N}]$ differences, and that $\delta^{13} \mathrm{C}$ was indexing realized water stress at the foliar-level. It is likely that $A_{\mathrm{n}}$ differed across the range of $[\mathrm{N}]$ found at the ponderosa pine sites $(1.00-1.36 \%)$ and therefore, the $\delta^{13} \mathrm{C}$ values would have underestimated the true spread in site water stress.

In addition, $\delta^{13} \mathrm{C}$ can be influenced more by radiation interception than water availability [43]. The ponderosa pine foliage samples were taken from the upper-canopy in dominant and co-dominant trees. It was thought this sample material would better represent an index of water stress across sites by minimizing differences in vapor pressure deficit, [N], and average irradiance. It is unlikely that self-shading of foliage was important in ponderosa pine, given the moderate LAIs of the stands in this study (1.4-3.3 projected). Total canopy intercepted PAR would have been $34-63 \%$ or $43-73 \%$ across the sites, estimated using the Beers-Lambert Law with extinction coefficients $(k)$ of 0.3 and 0.4 , respectively. A relatively low $k$ value is typical of Pinus species and reflects clumped shoots and incomplete canopy coverage [12]. Photosynthetic rates of individual needles are close to saturation at 30-35\% of full-sunlight in ponderosa pine $\left(600-700 \mu \mathrm{mol} \mathrm{m}^{-2} \mathrm{~s}^{-1}\right)$, although this saturation point is somewhat sensitive to canopy position [3].

Two confounding factors in this study that may explain the lack of significant tree- and stand-level covariates may be the inconsistent time of sampling and the bias induced by image analysis procedures. Although Pierce et al. [31] found no significant temporal difference in canopy-average SLA, Nippert and Marhsall [30] indicated that 1-year-old foliage in the upper canopy increased in SLA during the growing season. However, this effect should be relatively minor in our study because samples were not collected during the growing season. However, a different image analysis system was used to measure onesided leaf area for each of the three species. This confounding of species and measurement technique has the potential for introducing only minor measurement error for Douglas-fir and hybrid spruce due to their small and relatively flat needles. The use of image analysis to measure ponderosa pine needle surface area has been shown to be biased when compared to direct measurements [48]. However, pine surface area determined by image analysis can explain nearly $91 \%$ of the variation in measured surface area [48]. Although the ponderosa pine SLA values reported in this study may be biased for estimating alternative expressions of total surface area, our definition of SLA on the basis of projected leaf area was expedient to measure and served well as an indicator of needle condition and light gradients within crowns, between trees, and among stands.

\section{CONCLUSIONS}

Despite significant within- and between-stand variability, SLA was found to be relatively insensitive to tree- and standlevel factors after accounting for species, foliage age class, and location in the canopy in three ecologically-distinct conifer species in the Pacific Northwest. Decrease in SLA with foliage age was independent of species, while rate at which it decreased through the canopy was dependent on both foliage age class and species. Cardinal direction had a relatively minor influence on SLA within individual Douglas-fir and hybrid spruce crowns, but horizontal distance from the bole was a significant factor in hybrid spruce. However, SLA did significantly increase with stand age. This study provides a predictive equation that can be used to reconstruct within-stand variability of SLA for three important Pacific Northwest conifer species. Future work is needed to further understand factors influencing between-stand variability in SLA and this will likely be achieved by refining measurements of key environmental conditions like site water and radiation balances.

Acknowledgements: A. Weiskittel thanks the Swiss Needle Cast Cooperative and its supporting members as well as the numerous field and lab crew members that assisted with this project. H. Temesegen gratefully acknowledges the financial support of the British Columbia Ministry of Forests, Research Branch, the National Science and Engineering Research Council, and Forest Renewal BC for the data collection and analysis of this research. D. Wilson thanks the USDA Forest Service Deschutes National Forest for permission to destructively sample trees. Special thanks to Erwin Dreyer, John Kershaw, and one anonymous reviewer for helping to improve an earlier version of this manuscript.

\section{REFERENCES}

[1] Apple M., Tiekotter K., Snow M., Young J., Soeldner A., Phillips D., Tingey D., Bond B.J., Needle anatomy changes with increasing tree age in Douglas-fir, Tree Physiol. 22 (2002) 129-136.

[2] Bartelink H.H., Allometric relationships on biomass and needle area of Douglas-fir, For. Ecol. Manage. 86 (1996) 193-203.

[3] Bond B.J., Farnsworth B.T., Coulombe R.A., Winner W.E., Foliage physiology and biochemistry in response to light gradients in conifers with varying shade tolerance, Oecologia 120 (1999) 183192.

[4] Brooks J.R., Hinckley T.M., Sprugel D.G., Acclimation responses of mature Abies amabilis sun foliage to shading, Oecologia 100 (1994) 316-324.

[5] Chen H.Y.H., Klinka K., Kayahara G.J., Effects of light on growth, crown architecture, and specific leaf area for naturally established Pinus contorta var. latifolia and Pseudotsuga menziesii var. glauca saplings, Can. J. For. Res. 26 (1996) 1149-1157.

[6] Clement C.J., Banner A., Ecosystem mapping of the Date Creek silvicultural systems research area, BC Ministry of Forests, Victoria, BC, 1992, p. 33.

[7] Del Rio E., Berg A., Specific leaf area of Douglas-fir reproduction as affected by light and needle age, For. Sci. 25 (1979) 183-186.

[8] Ellsworth D.S., Reich P.B., Canopy structure and vertical patterns of photosynthesis and related leaf traits in a deciduous forest, Oecologia 96 (1993) 169-178.

[9] Evans J.R., Photosynthesis and nitrogen relationships in leaves of $\mathrm{C}_{3}$ plants, Oecologia 78 (1989) 9-19. 
[10] Farquhar G.D., Ehleringer J.R., Hubick K.T., Carbon isotope discrimination and photosynthesis, Ann. Rev. Plant Physiol. Plant Mol. Biol. 40 (1989) 503-537.

[11] Franklin J.F., Dyrness C.T., Natural vegetation of Oregon and Washington, USDA Forest Service General Technical Report GTRPNW-8, Portland, OR, 1973.

[12] Gholz H.L., Linder S., McMurtrie R.E., Environmental constraints on the structure and productivity of pine forest ecosystems: a comparative analysis, Munksgaard International Booksellers and Publishers, Copenhagen, Denmark, 1994.

[13] Gilmore D.W., Seymour R.S., Halteman W.A., Greenwood M.S., Canopy dynamics and the morphological development of Abies balsamea: effects of foliage age on specific leaf area and secondary vascular development, Tree Physiol. 15 (1995) 47-55.

[14] Gower S.T., Reich P.B., Son Y., Canopy dynamics and above ground production of five tree species with different leaf longevities, Tree Physiol. 12 (1993) 327-345.

[15] Hager H., Sterba H., Specific leaf area and needle weight of Norway spruce (Picea abies) in stands of different densities, Can. J. For. Res. 15 (1985) 389-392.

[16] Hollinger D.Y., Canopy organization and foliage photosynthetic capacity in a broad-leaved evergreen montane forest, Funct. Ecol. 3 (1989) 53-62.

[17] Ishii H., Ford E.D., Boscolo M.E., Manriquez A.C., Wilson M.E., Hinckley T.M., Variation in specific needle area of old-growth Douglas-fir in relation to needle age, within-crown position, and epicormic shoot production, Tree Physiol. 22 (2002) 31-40.

[18] Kennedy R.E., Causes and consequences of uncertainty in the application of a biogeochemical model to a large geographic region, Ph.D. dissertation, Department of Forest Science, Oregon State University, Corvallis, OR, 2004, p. 152.

[19] Kershaw J.A., Maguire D.A., Crown structure in western hemlock, Douglas-fir, and grand fir in western Washington: horizontal distribution of foliage within branches, Can. J. For. Res. 26 (1996) $128-142$.

[20] Maguire D.A., Bennett W.S., Patterns in the vertical distribution of foliage in young coastal Douglas-fir, Can. J. For. Res. 26 (1996) 1991-2005.

[21] Marshall J.D., Monserud R.A., Foliage height influences specific leaf area of three conifer species, Can. J. For. Res. 33 (2003) 164 170.

[22] Meidinger D., Pojar J., Ecosystems of British Columbia, Research Branch, British Columbia Ministry of Forests, Victoria, BC, 1991, p. 330.

[23] Meinzer F.C., Goldstein G., Grantz D.A., Carbon isotope discrimination and gas exchange in coffee during adjustment to different soil moisture regimes, in: Ehleringer J.R., Hall A.E., Farquhar G.D. (Eds.), Stable isotopes and plant carbon-water relations, Academic Press, San Diego, 1993, pp. 327-345.

[24] Morgan M.G., MacLean D.A., Piene H., Variation in balsam fir needle length due to crown position, foliage age, and intertree differences, For. Sci. 29 (1983) 412-422.

[25] Nagel L.M., O'Hara K.L., The influence of stand structure on ecophysiological leaf characteristics of Pinus ponderosa in western Montana, Can. J. For. Res. 31 (2001) 2173-2182.

[26] Niinemets Ü., Acclimation to low irradiance in Picea abies: influence of past and present light climate on foliage structure and function, Tree Physiol. 17 (1997) 723-732.

[27] Niinemets Ü., Ellsworth D., Lukjanova A., Tobias M., Dependence of needle architecture and chemical composition on canopy light availability in three North American Pinus species with contrasting needle length, Tree Physiol. 22 (2002) 747-761.

[28] Niinemets Ü., Kull O., Effects of light availability and tree size on the architecture of assimilative surface in the canopy of Picea abies: variation in needle morphology, Tree Physiol. 15 (1995) 307-315.
[29] Niinemets Ü., Kull O., Tenhunen J.D., An analysis of light effects on foliar morphology, physiology, and light interception in temperate deciduous woody species of contrasting shade tolerance, Tree Physiol. 18 (1998) 681-696.

[30] Nippert J.B., Marhsall J.D., Sources of variation in ecophysiological parameters in Douglas-fir and grand fir canopies, Tree Physiol. 23 (2003) 591-601.

[31] Pierce L.L., Running S.W., Walker J., Regional-scale relationships of leaf area index to specific leaf area and leaf nitrogen content, Ecol. Appl. 4 (1994) 313-321.

[32] Pinherio J.C., Bates D.M., Mixed-effects models in S and S-Plus, Springer-Verlag, New York, NY, 2000.

[33] Reich P.B., Walters M.B., Ellsworth D.S., Vose J.M., Volin J.C., Gresham C., Bowman W.D., Relationships of leaf dark respiration to leaf nitrogen, specific leaf area and leaf life-span: a test across biomes and functional groups, Oecologia 114 (1998) 471-482.

[34] Richardson A.D., Berlyn G.P., Ashton P.M.S., Thadani R., Cameron I.R., Foliar plasticity of hybrid spruce in relation to crown position and stand age, Can. J. Bot. 78 (2000) 305-317.

[35] Roberts J., Hopkins R., Morecroft M., Towards a predictive description of forest canopies from litter properties, Funct. Ecol. 13 (1999) 265-272.

[36] Sellin A., Kupper P., Spatial variation in sapwood area to leaf area ratio and specific leaf area within a crown of silver birch, Trees 20 (2006) 311-319.

[37] Specht R.L., Specht A., Canopy structure in Eucalyptus-dominated communities in Australia along climatic gradients, Acta. Oecol. 10 (1989) $191-213$.

[38] St. Clair J.B., Genetic variation in tree structure and its relation to size in Douglas-fir. II. Crown form, branch characters, and foliage characters, Can. J. For. Res. 24 (1994) 1236-1247.

[39] Sutton B.C.S., Pritchard S.C., Gawley J.R., Newton C.H., Kiss G.K., Analysis of Sitka spruce-interior spruce introgressions in British Columbia using cytoplasmic and nuclear DNA probes, Can. J. For. Res. 24 (1994) 278-285.

[40] Temesgen H., LeMay V.M., Cameron I.R., Bivariate distribution functions for predicting twig leaf area within hybrid spruce crowns, Can. J. For. Res. 33 (2003) 2044-2051.

[41] Temesgen H., Weiskittel A.R., Leaf mass per area relationships across light gradients in hybrid spruce crowns, Trees 20 (2006) 522530.

[42] Von Caemmerer S., Farquhar G.D., Some relationships between the biochemistry of photosynthesis and the gas exchange of leaves, Planta 153 (1981) 376-387.

[43] Warren C.R., McGrath J.F., Adams M.A., Water availability and carbon isotope discrimination in conifers, Oecologia 127 (2001) 476-486.

[44] Weiskittel A.R., Maguire D.A., Garber S.M., Kanaskie A., Influence of Swiss needle cast on foliage age class structure and vertical distribution in Douglas-fir plantations of north coastal Oregon, Can. J. For. Res. 36 (2006) 1497-1508.

[45] White J.D., Scott N.A., Specific leaf area and nitrogen distribution in New Zealand forests: Species independently respond to intercepted light, For. Ecol. Manag. 226 (2006) 319-329.

[46] Wilson D.S., Soil-site productivity relationships of Central Oregon ponderosa pine, Ph.D. dissertation, Department of Forest Resources, Oregon State University, Corvallis, OR, 2003, p. 103.

[47] Wood S., Generalized additive models, Chapman \& Hall/CRC, New York, NY, 2006.

[48] Wykoff W.R., Measuring and modeling surface area of ponderosa pine needles, Can. J. For. Res. 32 (2002) 1-8.

[49] Xiao C.-W., Janssens I.A., Yuste J.C., Ceulemans R., Variation of specific leaf area and upscaling to leaf area index in mature Scots pine, Trees 20 (2006) 304-310. 